Check for updates

Cite this: RSC Adv., 2017, 7, 20667

Received 27th February 2017

Accepted 3rd April 2017

DOI: $10.1039 / c 7 r a 02453 c$

rsc.li/rsc-advances

\section{Anaerobic lipopeptide biosurfactant production by an engineered bacterial strain for in situ microbial enhanced oil recovery}

\author{
Xiaolong Liang, ${ }^{\text {ab }}$ Rongjiu Shi, $\uparrow^{\mathrm{a}}$ Mark Radosevich, ${ }^{\mathrm{b}}$ Feng Zhao, ${ }^{\mathrm{c}}$ Yingyue Zhang, ${ }^{\mathrm{a}}$ \\ Siqin $\mathrm{Han}^{\mathrm{a}}$ and Ying Zhang (D)*a
}

Bacillus mojavensis JF-2 produces water-soluble lipopeptide under aerobic conditions, while Pseudomonas stutzeri DQ1 grows rapidly under anaerobic conditions. These bacteria were used to construct an engineered strain for anaerobic lipopeptide production by protoplast fusion for potential use in microbially enhanced oil recovery (MEOR). The resulting fusant strain FA-2 produced lipopeptide (382 $\mathrm{mg}^{-1}$ ) anaerobically at temperatures up to $50{ }^{\circ} \mathrm{C}$, across a $\mathrm{pH}$ range of $4.5-10.0$, and at salt concentrations as high as $10 \% \mathrm{NaCl}$. Experimental results from a physical simulation core at $39{ }^{\circ} \mathrm{C}$ suggest that FA-2 has potential for use in MEOR.

\section{Introduction}

Lipopeptides are extraordinary biosurfactants that are well known for reducing surface tension and interfacial tension between oil and water, thus playing a crucial role in microbial enhanced oil recovery (MEOR). ${ }^{\mathbf{1} 2}$ Lipopeptides also exhibit exceptional emulsifying, foaming, antiviral and antimycoplasma properties, and are widely used in many other areas. Biosurfactants have several advantages over chemical surfactants such as: lower toxicity, higher environmental compatibility, biodegradability, higher surface activity, lower critical micelle concentration and synthesis from renewable raw materials. ${ }^{3-5}$ However, most screened biosurfactant producing bacterial strains are aerobic organisms. ${ }^{6-9}$ As the underground environment of petroleum reservoirs is anaerobic, ${ }^{\mathbf{1 0 , 1 1}}$ these organisms would not be effective for in situ microbial enhanced oil recovery. ${ }^{\mathbf{1 2 - 1 5}}$ High temperatures, high salinity and low oxygen content in oil reservoirs are known to adversely impact microbial growth and their metabolites production. ${ }^{16-18}$ Considerable effort has been expended to isolate bacterial strains that can function under reservoir conditions for MEOR, but few strains have been isolated and characterized.

Though very few anaerobic biosurfactant-producing bacteria have been characterized, interest in anaerobic biosurfactant

${ }^{a}$ Key Laboratory of Pollution Ecology and Environmental Engineering, Institute of Applied Ecology, Chinese Academy of Sciences, Shenyang, Liaoning Province 110016, China.E-mail:yzhang207@yahoo.com; yzhang@iae.ac.cn; Tel: +862483970370

${ }^{b}$ Biosystems Engineering \& Soil Science Department, University of Tennessee, Knoxville, Tennessee, 37996, USA

'State Key Laboratory of Urban Water Resource and Environment, School of Municipal and Environmental Engineering, Harbin Institute of Technology, Harbin 150090, China

$\dagger$ Co-first author. production has steadily increased given the potential use in enhanced oil recovery. ${ }^{\mathbf{1 2 , 1 3 , 1 9 , 2 0}}$ In MEOR, both the above ground production and the underground production have been undertaken; however, above ground production is costly and complicated. ${ }^{21}$ The in situ application is more cost-effective, longer lasting, more simply implemented and has a wide range of applications, making it advantageous for MEOR. ${ }^{22}$ Obtaining microorganisms for anaerobic biosurfactant production that can tolerate oil reservoir conditions such as extremes of $\mathrm{pH}$, temperatures and salinity is prerequisite for in situ surfactant production..$^{15-18}$ In the absence of suitable native strains, molecular and genetic engineering tools have been used to modify microorganisms to improve their tolerance to harsh reservoir conditions that produce biosurfactants for MEOR. ${ }^{23,24}$

Protoplast fusion is a common technique for engineering bacteria and has been used to create new strains with desired properties by combining genomes from different organisms. Here, intergeneric protoplast fusion was performed between Bacillus mojavensis JF-2 and Pseudomonas stutzeri DQ-1. B. mojavensis $\mathrm{JF}-2,{ }^{25,26}$ capable of producing lipopeptide with excellent properties, was isolated from oil-field injection brine, and its ability to produce biosurfactant has been characterized. ${ }^{27-31}$ Several previous works reported that JF-2 produced lipopeptide biosurfactants under anaerobic conditions; ${ }^{26-29,31}$ however, it has been described that this anaerobic lipopeptide production is limited, unstable, and requires the addition of deoxyribonucleosides or DNA supplements to the culture medium. ${ }^{29}$ Surfactant-producing capability of JF-2 will be lost when cultured repeatedly which causes problems for field trials and large-scale biosurfactant production. ${ }^{31}$ The JF-2 strain adopted in this study can only grow and produce lipopeptide aerobically which means the loss of anaerobic biosurfactantproducing ability. P. stutzeri DQ-1 grows rapidly under 
anaerobic conditions but does not produce biosurfactant. The current investigation was aimed at engineering a new strain with the combined characteristics of rapid anaerobic growth and stable lipopeptide production by protoplast fusion. The resulting strain, FA-2 possessed the desired characteristics and exhibited potential for MEOR under the harsh conditions typical of petroleum reservoirs.( $($ )

\section{Experimental}

\subsection{Strains and media}

Bacillus mojavensis JF-2 (ATCC 39307), obtained from the American Type Culture Collection (Manassas, VA), and Pseudomonas stutzeri DQ-1, isolated from Daqing Oil Field (PetroChina Company Ltd., Heilongjiang Province, China), were used as parent strains for fusion experiments.

Bacteria were incubated in complete medium consisting of $10 \mathrm{~g}$ per liter of tryptone, $5 \mathrm{~g}$ of yeast extract, $5 \mathrm{~g}$ of beef extract, $5 \mathrm{~g}$ of sodium chloride and $10 \mathrm{~g}$ of glucose per liter. Lysozyme was dissolved in SMM buffer (0.5 M sucrose, $0.02 \mathrm{M} \mathrm{MgCl}_{2}$, $0.02 \mathrm{M}$ maleic acid, $\mathrm{pH} 6.8$ ) and kept at $-20{ }^{\circ} \mathrm{C}$.

Anaerobic fermentation medium (AFM) was used for anaerobic fermentation of the fusant. AFM was composed of sucrose (32 g per liter), $\mathrm{NaCl}$ ( $5 \mathrm{~g}$ per liter), $\mathrm{KCl}$ ( $1 \mathrm{~g}$ per liter), $\mathrm{KH}_{2} \mathrm{PO}_{4}$ (5.7 g per liter), $\mathrm{K}_{2} \mathrm{HPO}_{4}$ (5.25 g per liter), $\mathrm{NaNO}_{3}$ (3 g per liter), $\mathrm{MgSO}_{4}(0.25 \mathrm{~g}$ per liter$), \mathrm{CaCl}_{2}$ ( $0.16 \mathrm{~g}$ per liter), and yeast extract (2.7 $\mathrm{g}$ per liter). Anaerobic culture preparation was performed as modified by Javaheri ${ }^{31}$ by boiling the medium under a stream of oxygen-free nitrogen.

\subsection{Protoplast preparation}

The parent strains JF-2 and DQ-1 were incubated in $50 \mathrm{ml}$ complete medium and cultivated at $40{ }^{\circ} \mathrm{C}$ and $37{ }^{\circ} \mathrm{C}$ respectively. When the optical density $(600 \mathrm{~nm})$ reached approximately 1.0, the cells were harvested by centrifugation at $3000 \times g$ at $4{ }^{\circ} \mathrm{C}$ for $10 \mathrm{~min}$ and then washed twice with sterile normal saline solution ( $9 \mathrm{~g}$ per liter sodium chloride, $\mathrm{pH}$ 6.8). The cells were resuspended in $20 \mathrm{ml} \mathrm{SMM}$ buffer containing lysozyme (3 $\mathrm{mg}$ $\mathrm{ml}^{-1}$ for JF-2 and $6 \mathrm{mg} \mathrm{ml}{ }^{-1}$ for DQ-1) and then shaken at $100 \mathrm{rpm}$ and $37^{\circ} \mathrm{C}$ to complete protoplast formation, $50 \mathrm{~min}$ enzymolysis for JF-2 and 80 min enzymolysis for DQ-1. ${ }^{32}$

\subsection{Protoplast inactivation}

JF-2 protoplast suspensions were transferred into sterile tubes and incubated at $65{ }^{\circ} \mathrm{C}$ in a water bath for $160 \mathrm{~min}$ to achieve complete inactivation in which the protoplasts cannot get regenerated. DQ-1 protoplast suspensions $(3 \mathrm{ml})$ were transferred to a sterile Petri dish (6 $\mathrm{cm}$ diameter) and then placed under a preheated $30 \mathrm{~W}$ ultraviolet lamp at a vertical distance of $20 \mathrm{~cm}$ for 40 minute irradiation to inactivate DQ-1 completely. The inactivated DQ-1 protoplasts were maintained in the dark for $2 \mathrm{~h}$ to avoid photo reactivation repair. Inactivation was verified by lack of growth on regeneration medium.

\$ Engineered FA-2 for in situ MEOR.

\subsection{Protoplast fusion and regeneration}

Inactivated protoplast suspensions of the two parent strains were gently mixed in a $10 \mathrm{ml}$ centrifuge tube and incubated at $30{ }^{\circ} \mathrm{C}$. After $5 \mathrm{~min}$, the tube was centrifuged at $2500 \times g$ for $10 \mathrm{~min}$ and then resuspended in $0.5 \mathrm{ml} \mathrm{SMM} \mathrm{buffer.} \mathrm{Fusogenic}$ agent (1.5 ml, SMM buffer containing 40\% PEG6000, w/v) was added with mild shaking for homogenization and then incubated at $30{ }^{\circ} \mathrm{C}$ for $5 \mathrm{~min}$. The cells were collected by centrifugation $(2500 \times g$, for $10 \mathrm{~min})$ at $4{ }^{\circ} \mathrm{C}$ and then added in $2 \mathrm{ml}$ SMM buffer. Protoplasts were diluted with SMM buffer, centrifuged at $2500 \times g$ for $10 \mathrm{~min}$, and diluted again. Serial dilutions of the protoplast suspension $(0.1 \mathrm{ml})$ were applied on the regeneration blood agar and incubated at $37^{\circ} \mathrm{C}$ in an anaerobic box (MGC AnaeroPack C-31, Titsubishi) for 4 to 7 days.

\subsection{Screening of fusants}

The single colonies that caused hemolytic circles were isolated from anaerobic box and then incubated into anaerobic media. Each strain was cultured in triplicate anaerobically at $37^{\circ} \mathrm{C}$ for $48 \mathrm{~h}$. The surface tension and the oil displacement activity of the culture broths were measured to demonstrate the ability of anaerobic biosurfactant production. A tension meter (BZY-1, Shanghai HENGPING Co. Ltd) was used to determine the surface tension of the cell-free supernatant. A single fusant strain designated FA-2 with the desired characteristics was isolated through this screening process.

\subsection{Evaluation of fusant}

B. mojavensis JF-2, P. stutzeri DQ1 and fusant FA-2 were inoculated on complete media respectively and cultured for $50 \mathrm{~h}$ at $37{ }^{\circ} \mathrm{C}$, and then their colonial morphologies were compared. Scanning electronic microscope (SEM, FEI Company Quanta $^{\text {TM}} 250$, USA) was employed to observe microscopic surface features of the bacterial cells.

The effects of temperature, salt concentration, and $\mathrm{pH}$ on anaerobic growth of the FA-2 were determined. The surface tension was performed to assess the surface activity of produced biosurfactant, and the biosurfactant activity was measured by the oil-spreading technique. ${ }^{33}$ The effect of temperature on the growth and surfactant production of FA-2 was examined at 20$60{ }^{\circ} \mathrm{C}$. The anaerobic culture media supplemented with $1-25 \%$ $\mathrm{NaCl}$ were used to investigate the effect of salt concentration on the growth and surfactant production of FA-2. The pH was varied from 3.5 to 11 to determine the range and optimal $\mathrm{pH}$ for growth and surfactant production. The tests for temperature, salt, and $\mathrm{pH}$ were performed at $40{ }^{\circ} \mathrm{C}$.

\subsection{Optimization of carbon and nitrogen sources}

The effect of various carbon sources on the anaerobic growth of FA-2 was assessed by growing the strain in MS medium ( $\mathrm{pH} 7.2$ ) supplemented with $0.5 \%(\mathrm{w} / \mathrm{v})$ yeast extract, and $2 \%(\mathrm{w} / \mathrm{v})$ of either glucose, glycerol, molasses, sucrose, sunflower seed oil, coconut oil, olive oil, ${ }^{34}$ soybean oil, liquid paraffin, or crude oil at $40{ }^{\circ} \mathrm{C}$ for 36 hours. Similarly, the effects of various nitrogen sources on growth was determined by growing the organism in 
the MS medium ( $\mathrm{pH} 7.2)$ supplemented with $1 \%(\mathrm{w} / \mathrm{v})$ of either yeast extract, tryptone, soy bean flour or corn steep powder. The MS medium supplemented with $0.5 \% \mathrm{NaNO}_{3}, \mathrm{KNO}_{3}, \mathrm{NH}_{4} \mathrm{NO}_{3}$, $\mathrm{NH}_{4} \mathrm{Cl}$, or $\left(\mathrm{NH}_{4}\right)_{2} \mathrm{SO}_{4}$ were used to investigate the effect of inorganic nitrogen sources on anaerobic growth and surfactant production of FA-2. After inoculation, broths were centrifuged at $5000 \times g$ for 10 minutes at $4{ }^{\circ} \mathrm{C}$ and the surface tension and the diameter of oil spreading circle of individual supernatants was measured to estimate the biosurfactant production. ${ }^{21}$

\subsection{Growth of FA-2 under anaerobic conditions}

Anaerobic cultures were prepared by boiling the medium followed by cooling under a stream of oxygen-free nitrogen. FA-2 cultures (logarithmic phase) were centrifuged to obtain cells and then washed thrice to remove the residual biosurfactant. The cells were resuspended and inoculated into a MD-500 laboratory fermenter (L.E. MARUBISHI, MD-500 bioreactor, Japan). The inoculation dose was $5 \%, \mathrm{v} / \mathrm{v}$. The bioreactor, equipped with $\mathrm{pH}$, DO, oxidation-reduction potential (ORP), and temperature probes, had a total volume of $10 \mathrm{l}$ and was enclosed and only interconnected with a nitrogen gas bag to guarantee anaerobic conditions. Cultivation was performed at $37^{\circ} \mathrm{C}$ using $6 \mathrm{l}$ of media with the agitation speed of $120 \mathrm{rpm}$. The initial $\mathrm{pH}$ was approximately 7.5 and no $\mathrm{pH}$ adjustment was performed.

\subsection{Biosurfactant extraction and analysis}

Overnight seed cultures of FA-2 were inoculated (5\%, v/v) into $3000 \mathrm{ml}$ of medium $\mathrm{E}$ supplemented with $0.1 \% \mathrm{NaNO}_{3}$ and $0.1 \%$ yeast extract under strictly anaerobic conditions, ${ }^{35}$ and then shaken at $100 \mathrm{rpm}$ for $72 \mathrm{~h}$. The culture broth was centrifuged (Himac Centrifuge SCR20BA, HITACHI) at $10000 \times g$ for $20 \mathrm{~min}$ at $4{ }^{\circ} \mathrm{C}$ to obtain a cell-free supernatant. The supernatant was treated with $6 \mathrm{~mol} \mathrm{l}^{-1} \mathrm{HCl}$ to adjust the $\mathrm{pH}$ to 2.0 and placed at $4{ }^{\circ} \mathrm{C}$ for overnight for acid precipitation. The precipitate was harvested by centrifugation at $10000 \times g$ for $30 \mathrm{~min}$ at $4{ }^{\circ} \mathrm{C}$. The product was leached thrice with a $2: 1$ chloroform-methanol mixture. The organic phase was collected to concentrate biosurfactant using a rotary evaporator (RE-2000, Shanghai YARONG) at $50{ }^{\circ} \mathrm{C}$ after which the precipitates were redissolved and transferred to a lyophilizer. The mass of freeze-dried extract was measured to determine the yield of crude biosurfactant.

The biosurfactant was first identified by thin-layer chromatography (TLC), modified from Cooper. ${ }^{36}$ A sample of biosurfactant was dissolved in methanol and spotted on silica gel plates, which were eluted with chloroform/methanol (10:9, v/ $\mathrm{v}$ ). The ninhydrin reagent (composed of $0.3 \%$ ninhydrin and $3 \%$ glacial acetate acid in butanol) was evenly sprayed to the sheets. The sheets were put into $95{ }^{\circ} \mathrm{C}$ oven for drying. The lipopeptide was determined by appearance of a red spot on the plate.

Fourier transform infrared spectroscopy (FT-IR) analysis was employed to identify the molecular structure of the biosurfactant. The sample was dissolved in dichloromethane and then subjected to FT-IR (NICOLET380, Thermo Electron Corporation, USA). FT-IR spectra were collected between 400 and $4000 \mathrm{~cm}^{-1}$ wave numbers.

\subsection{Liquid chromatography/tandem mass spectrometry analysis}

The crude biosurfactant was further analyzed by liquid chromatography-mass spectrometry (LC-MS) as described previously. ${ }^{37}$ A TSQ Quantum Access Max Triple Quadrupole mass spectrometer (Thermo Scientific, San Jose, CA) equipped with a reversed-phase HPLC column (Waters Atlantis T3 Column, Waters Corporation, Dublin, Ireland, $\varphi 2.1 \times 150 \mathrm{~mm}$ ) was used. Chromatographic analysis was carried out using a gradient elution program [acetonitrile $: \mathrm{H}_{2} \mathrm{O}$ ( $1 \%$ trifluoroacetic acid), 10\% : 90\%, v/v (0-20 min); 60\% : 40\%, v/v (20-30 $\mathrm{min}) ; 100 \%: 0$, $\mathrm{v} / \mathrm{v}(30-50 \mathrm{~min})]$ at a flow rate of $0.3 \mathrm{ml} \mathrm{min}^{-1}$. The absorbance was detected at $220 \mathrm{~nm}$. All detection was in positive mode.

Further MS2 measurement on $[\mathrm{M}+\mathrm{H}]^{+}$ion of the metabolite was conducted on the LC-MS machine described above using the same program.

\subsection{CMC, emulsification capacity, oil displacement, biosurfactant stability}

The surface tension of a series of biosurfactant concentrations was measured for the determination of critical micelle concentration (CMC). ${ }^{38}$ A stock solution of the crude biosurfactant $\left(1 \mathrm{~g} \mathrm{l}^{-1}\right)$ was prepared in distilled water and various dilutions were made to obtain the concentrations from 10 to $150 \mathrm{mg} \mathrm{l}^{-1}$. The CMC was determined from the plateau in the curve of surface tension to biosurfactant concentration.

Emulsification capacity for different hydrophobic substrates was determined by measuring the emulsification index $\left(E_{24}\right)$ according to Cooper and Goldenberg. ${ }^{39}$ For this determination, $4 \mathrm{ml}$ of biosurfactant solution was blended with $6 \mathrm{ml}$ of hydrocarbons, i.e., liquid paraffin, kerosene, crude oil, olive oil,

Table 1 The surface tension, diameter of oil spreading circle of culture broths, and cell growth of recombinant strains under anaerobic conditions. All strains were grown in triplicate anaerobically. Triplicate cultures of each strain were analyzed and mean values were shown

\begin{tabular}{llrc}
\hline & $\begin{array}{l}\text { Surface tension } \\
\left(\mathrm{mN} \mathrm{m}^{-1}\right)\end{array}$ & $\begin{array}{l}\text { Diameter of oil } \\
\text { spreading circle }(\mathrm{mm})\end{array}$ & OD600 \\
\hline CK & $60.9 \pm 2.3$ & $2 \pm 0$ & $0 \pm 0$ \\
FA-1 & $49.1 \pm 1.6$ & $3 \pm 1$ & $1.7 \pm 0.2$ \\
FA-2 & $26.6 \pm 1.1$ & $26 \pm 3$ & $1.6 \pm 0.1$ \\
FA-3 & $33.2 \pm 2.2$ & $16 \pm 5$ & $1.2 \pm 0.3$ \\
FA-4 & $50.9 \pm 2.5$ & $3 \pm 1$ & $0 \pm 0$ \\
FA-5 & $29 \pm 1.3$ & $18 \pm 2$ & $1.2 \pm 0.2$ \\
FA-6 & $31.3 \pm 1.2$ & $15 \pm 4$ & $1.4 \pm 0.1$ \\
FA-7 & $39.8 \pm 3.3$ & $5 \pm 1$ & $1.3 \pm 0.2$ \\
FA-8 & $41.3 \pm 2.1$ & $4 \pm 1$ & $0.3 \pm 0.1$ \\
FA-9 & $39.2 \pm 2.7$ & $6 \pm 2$ & $0.4 \pm 0.1$ \\
FA-10 & $41.1 \pm 1.9$ & $5 \pm 1$ & $0.6 \pm 0.1$ \\
FA-11 & $36.8 \pm 1.2$ & $7 \pm 2$ & $0.9 \pm 0.2$ \\
FA-12 & $29.6 \pm 2.8$ & $17 \pm 3$ & $1.1 \pm 0.2$ \\
FA-13 & $30.3 \pm 2.1$ & $16 \pm 6$ & $0.9 \pm 0.3$ \\
FA-14 & $27.8 \pm 1.3$ & $19 \pm 1$ & $1.3 \pm 0.2$ \\
FA-15 & $39.9 \pm 3.8$ & $4 \pm 2$ & $1.1 \pm 0.2$ \\
FA-16 & $45.4 \pm 3.3$ & $3 \pm 0$ & $0.7 \pm 0.3$ \\
FA-17 & $38.5 \pm 2.6$ & $6 \pm 2$ & $0.8 \pm 0.2$ \\
FA-18 & $30.2 \pm 0.3$ & $15 \pm 3$ & $1.2 \pm 0.3$
\end{tabular}




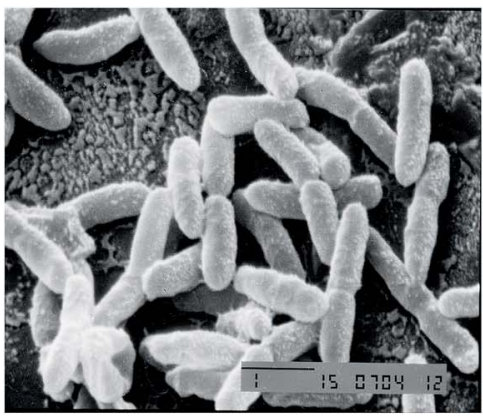

(a)

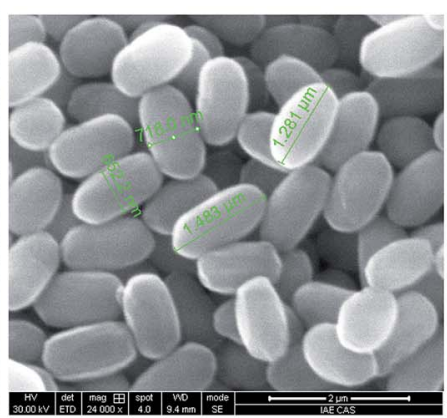

(b)

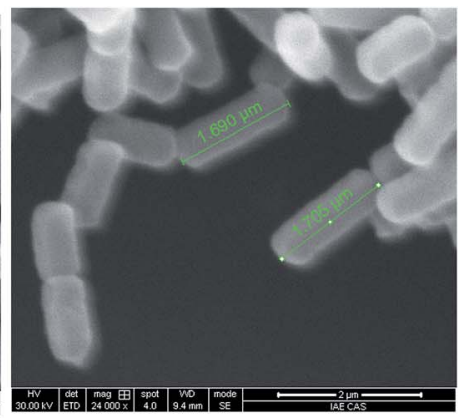

(c)

Fig. 1 Scanning electron microscope images of $P$. stutzeri DQ-1 (a), B. mojavensis JF-2 (b) and fusant strain FA-2 (c). The cells were surveyed under $24000 \times$ scale and the green bars show the length and width of each cell.

$n$-heptane and xylene, and vigorously vortexed for $2 \mathrm{~min}$. The mixtures were allowed to stand for $24 \mathrm{~h}$ at room temperature. The emulsification index $\left(E_{24}\right)$ was calculated using the following equation: $E_{24}(\%)=H_{\mathrm{EL}} / H_{\mathrm{S}} \times 100$, where, $H_{\mathrm{EL}}$ is the height of the emulsion layer, and $H_{\mathrm{S}}$ is the height of the total liquid column.
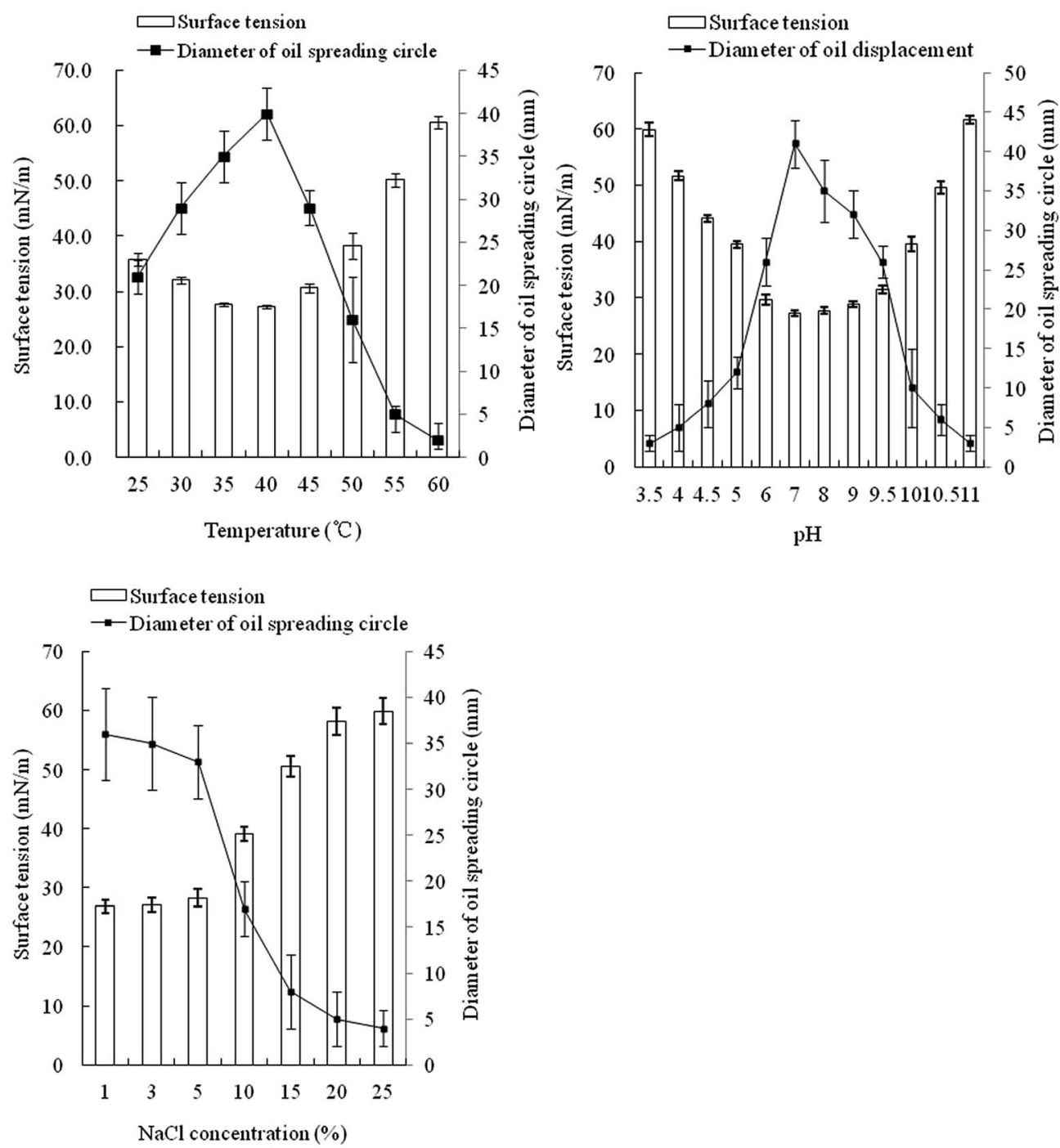

Fig. 2 Effect of temperature, $\mathrm{pH}$, and salinity on surface activity and biosurfactant production of the fusant FA-2 culture. Data points are the mean value of triplicate samples. Error bars show the corresponding standard deviation. 
To measure oil displacement activity of the biosurfactant, twenty milliliters of distilled water was added to a Petri dish (90 $\mathrm{mm}$ of diameter), followed by the addition of $20 \mu \mathrm{l}$ of crude oil to the surface of the water. Ten microliters of a culture was added to the center of the oil layer. ${ }^{\mathbf{4 0 4 1}}$ The diameters of clear zones were measured for triplicate samples.

Biosurfactant stability at various $\mathrm{pH}$ ranging from $\mathrm{pH} 3-11$, salt concentrations from $3-25 \%$ and temperatures from 20 $121{ }^{\circ} \mathrm{C}$ were determined. Biosurfactant was exposed to each of these conditions for $3 \mathrm{~h}$, and then the surface tension and $E_{24}$ were measured at room temperature.

\subsection{Physical simulation core flooding experiment}

The effectiveness of fusant FA-2 for MEOR was tested in an artificial core at $39{ }^{\circ} \mathrm{C}$ simulating the oil reservoir conditions at Luliang, Xinjiang Oil Field. Each stainless-steel column was packed with an artificial core made of original rock from oil reservoir (inner diameter $3.2 \mathrm{~cm}$, length $29.9 \mathrm{~cm}$, pore volume $60.0 \mathrm{ml}$ ) with $373.3 \mathrm{~cm} \mathrm{~d}^{-1}$ permeability. Two columns were used for the experiment and the columns simulated the heterogeneity of the reservoir rock. The columns were saturated with oil-field injected water of Luliang after vacuum pumping and then flooded with crude oil of Luliang until residual brine was saturated. After aging at $39{ }^{\circ} \mathrm{C}$ for $24 \mathrm{~h}$, the columns were flooded again with injected water until the water cut of produced liquid was higher than $98 \%$. Then, 1 pore volume (PV) of anaerobic medium inoculated with $10 \%$ bacteria FA-2 was injected into the column (JZ-14 2), while the control column (JZ14 20) was injected 1 PV of anaerobic medium, and both columns were incubated at $39{ }^{\circ} \mathrm{C}$ for $10 \mathrm{~d}$. In the subsequent water flooding, the same injected water was used to flood the column. The flow velocity for the flooding was set at $1 \mathrm{ml} \mathrm{min}{ }^{-1}$. The volume of oil released and the water cut in the produced water were measured. The enhanced oil recovery (EOR) (\%) and water cut $(\%)$ were calculated as the description by Sun. ${ }^{23}$

\section{Results and discussion}

\subsection{Screening of fusants}

In this study, 356 fusant strains were obtained, and 18 colonies that produced hemolysis circles were isolated preliminarily and incubated in anaerobic medium in anaerobic pipes. The selected fusant strains were named FA-1-FA-18. FA-2 had the most effective biosurfactant-producing capability based on the largest diameter of the oil spreading assay and therefore was chosen for further study (Table 1).

\subsection{Comparison of fusant FA-2 to parent strains}

The differences in colony morphology between parent strains and FA-2 were significant. The colony of B. mojavensis JF-2 was volcano-shaped and white in color, while that of FA-2 was flat, yellow-white, dry, and circular. The colonial diameters of parent strain JF-2 were 3-6 mm. In contrast, the colony of FA-2 was larger (12-15 $\mathrm{mm})$. Scanning electron microscopy revealed that FA-2 was morphologically dissimilar to either of the parent strains (Fig. 1).
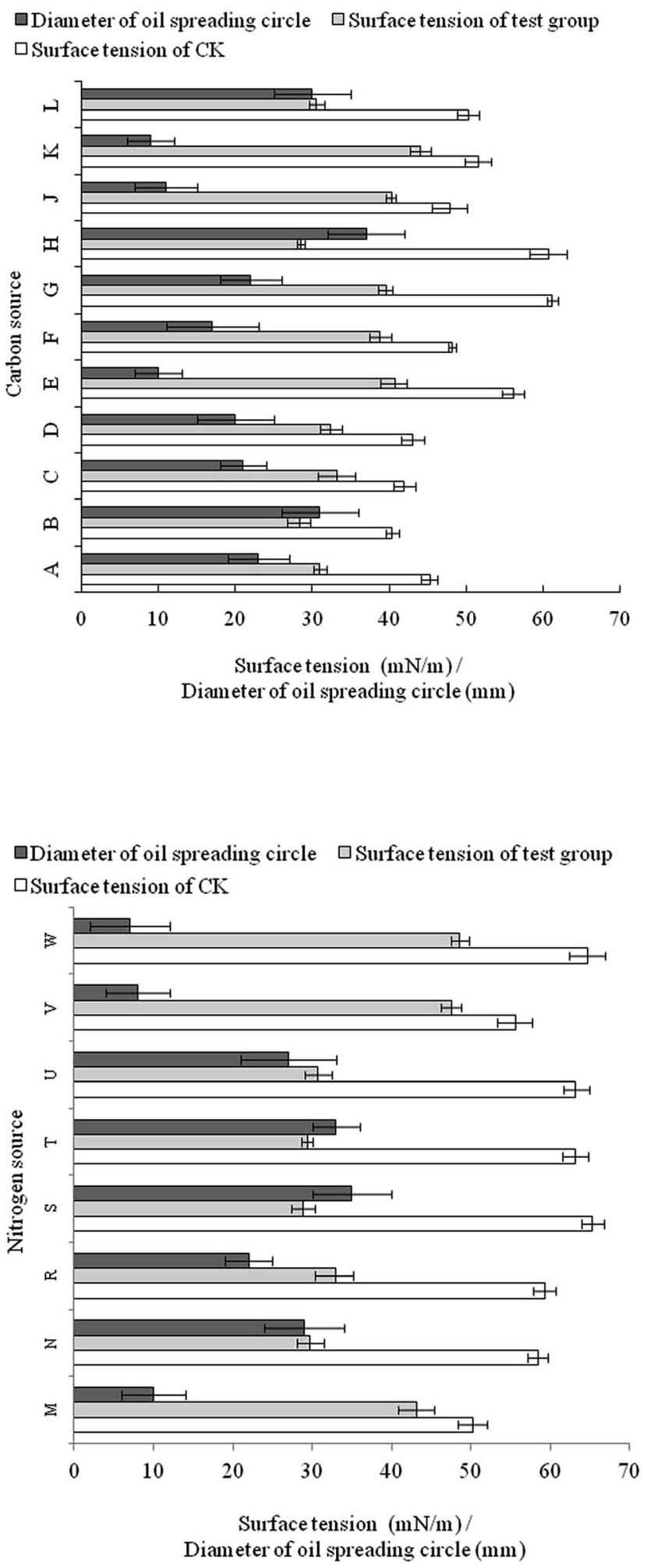

Fig. 3 Effect of various carbon and nitrogen sources on biosurfactant production and surface activity of the fusant strain FA-2. Data points are the mean values of triplicate samples. Carbon sources, (A) sunflower seed oil; (B) coconut oil; (C) olive oil; (D) soybean oil; (E) liquid paraffin; (F) crude oil; (G) glycerol; (H) sucrose; (J) corn steep powder; (K) molasses; (L) glucose. Nitrogen sources, (M) corn steep powder; (N) yeast extract; (R) tryptone; (S) sodium nitrate; $(T)$ ammonium nitrate; (U) potassium nitrate; (V) ammonium sulfate; (W) ammonium chloride. 
FA-2 grew well anaerobically exhibiting a maximum optical density of 1.4-1.8 (600 nm) while JF-2 grew poorly reaching a maximum OD of only $0-0.1$. The hereditary stability of FA-2's anaerobic lipopeptide production was tested by subculturing the engineered strain. FA-2 exhibited rapid anaerobic growth and surfactant production after 10 successive subcultures, suggesting that FA-2 had high genetic stability. FA-2 had no loss of lipopeptide-production capacity even subcultured sequentially which demonstrated stable genetic characteristics and reliable potential in field trial.

\subsection{The effects of temperature, salt concentration, and $\mathrm{pH}$ on anaerobic growth of FA-2}

The optimal temperature for strain FA-2 to produce biosurfactant was $40{ }^{\circ} \mathrm{C}$, same with the in situ temperature of Luliang. Within $25-50{ }^{\circ} \mathrm{C}$, the surface tension of the culture broth was distinctly lowered, but lower temperature or higher temperature would cause decline in biosurfactant production (Fig. 2). FA-2 functioned well in a wide range of $\mathrm{pH}$ (4.5-10.0), but favored neutral and slightly alkaline environment. The diameter of the oil spreading circle and surface tension of culture broth was linearly correlated with the yield of biosurfactant. ${ }^{41}$ Biosurfactant production of FA-2 was inhibited by high salt concentration, dropping significantly when the $\mathrm{NaCl}$ concentration was over $10 \%$.

\subsection{Optimization of carbon and nitrogen sources}

Sucrose was the best carbon source tested with respect to surfactant yield efficiency, since it had the most significant reduction in surface tension (from 60.7 to $28.5 \mathrm{mN} \mathrm{m}^{-1}$ ) and the largest oil spreading circle (37 mm) (Fig. 3). The effect of glucose was slightly inferior to sucrose. Vegetable oil could also be utilized by FA-2 for growth and biosurfactant production. As complex $\mathrm{C}$ and $\mathrm{N}$ sources, corn steep powder and molasses were not well utilized by FA-2.

For nitrogen source utilization, all the nitrates contributed to biosurfactant production as the surface tension of culture broth was below $30 \mathrm{mN} \mathrm{m}^{-1}$ and the diameter of oil spreading circle was over $27 \mathrm{~mm}$. Yeast extract was also a suitable nitrogen source for biosurfactant production since the surface tension dropped to $29.7 \mathrm{mN} \mathrm{m}^{-1}$ and the diameter of oil spreading circle was $29 \mathrm{~mm}$ (Fig. 3).

\subsection{Biosurfactant determination}

The output of the crude biosurfactant was $382 \mathrm{mg} \mathrm{l}^{-1}$ which was considerable. Huge amount of bacterial strains was obtained with prominent biosurfactant production in previous studies. Wickerhamomyces anomalus PY189 produced $570 \mathrm{mg}$ $1^{-1}$ of biosurfactant under optimized conditions reducing the surface tension of the media from $42.5 \mathrm{mN} \mathrm{m}^{-1}$ to $36.5 \mathrm{mN}$ $\mathrm{m}^{-1}$ after 7 days of cultivation..$^{42}$ Raw glycerol was used as the sole carbon source for biosurfactant production by Bacillus subtilis LSFM-05, and the highest yield $\left(1370 \mathrm{mg} \mathrm{l}^{-1}\right)$ of biosurfactant was get at $60 \mathrm{~h}$ of incubation. ${ }^{43}$ Highest production of biosurfactant, 844, 755 and $2158 \mathrm{mg} \mathrm{l}^{-1}$ for Bacillus subtilis \#309, \#311 and \#573 respectively, were yielded using sucrose as the carbon source. ${ }^{16}$ Maximal production of $1500 \mathrm{mg} \mathrm{l}^{-1}$ of surfactin was yielded by Bacillus subtilis ATCC 21332 with $\mathrm{Mn}^{2+}$ addition. ${ }^{44}$ The production of the biosurfactant in our study

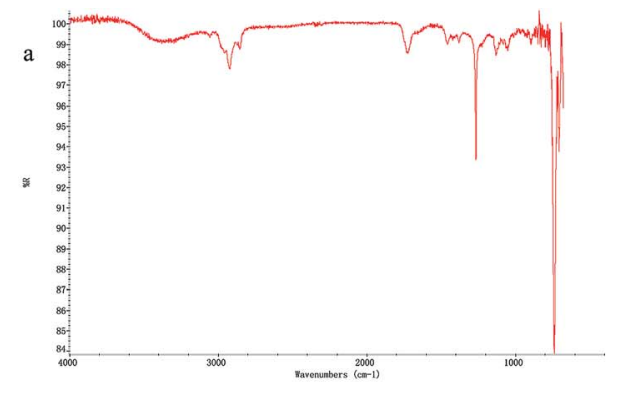

b
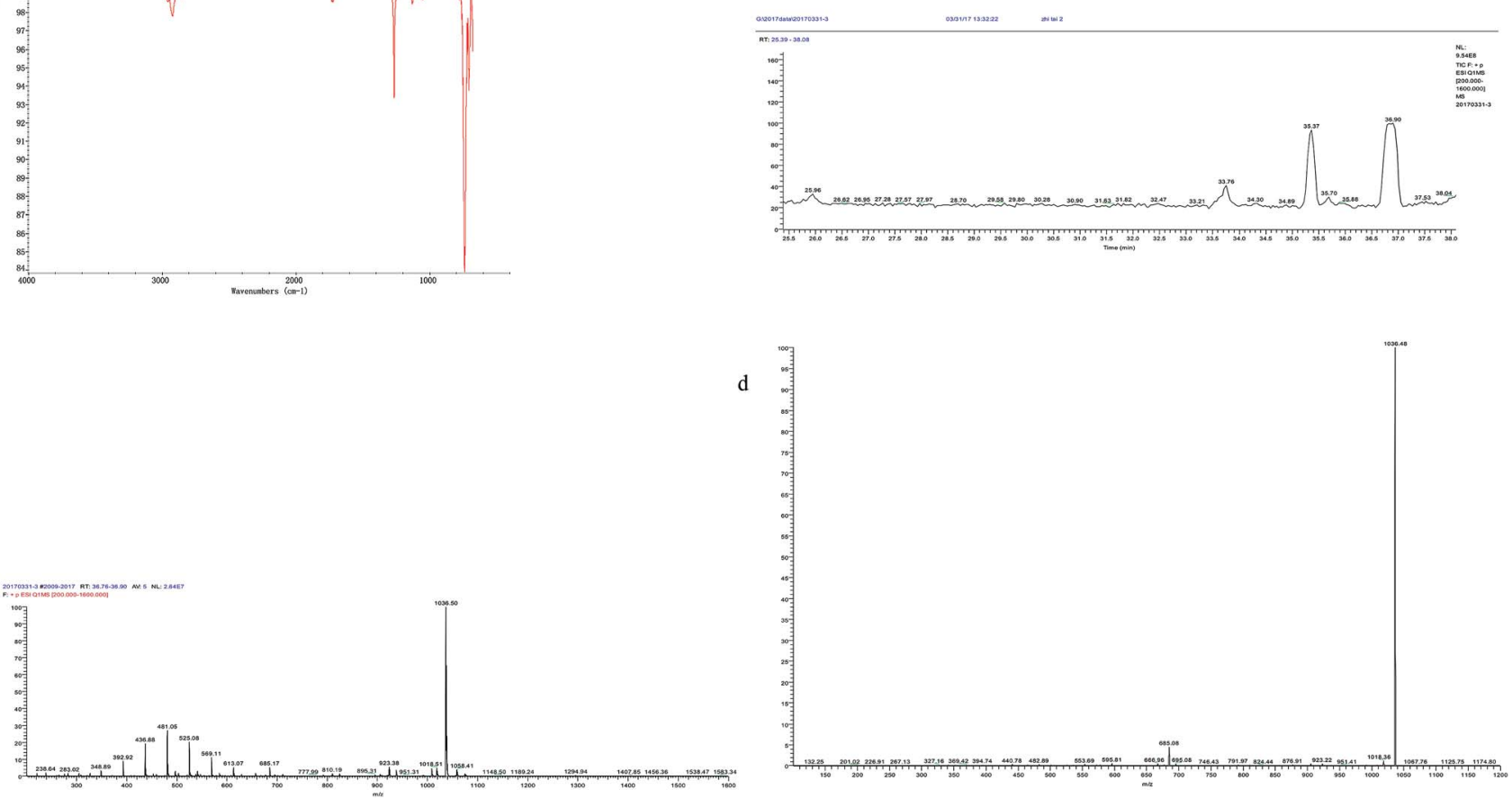

Fig. 4 (a) FTIR spectrum of the crude biosurfactant recovered from cell-free supernatant of FA-2; (b) reversed phase high-performance liquid chromatography of purified biosurfactant; (c) tandem mass spectra of peak 35.37 in (b); (d) tandem mass spectra of peak 36.90 in (b). 
was lower than that in the studies mentioned above; however, the biosurfactant from FA-2 was obtained from anaerobic culture and was demonstrated with higher surface activity.

A sample spotted on TLC plates and stained with ninhydrin revealed red spots on silica plates indicating the material contained amino acids. The IR spectrum showed bands characteristic of peptide bonds at $3400 \mathrm{~cm}^{-1}$ (stretching mode of $\mathrm{NH}$ ) and at $1651 \mathrm{~cm}^{-1}$ (CO-N bond stretching mode) (Fig. 4). The bands at $1436 \mathrm{~cm}^{-1}$ and $1258 \mathrm{~cm}^{-1}$ suggested the presence of aliphatic chains $\left(-\mathrm{CH}_{3}-,-\mathrm{CH}_{2}-\right)$ (Fig. 4). These results imply the presence of a peptide-like moiety as well as aliphatic hydrocarbons in the biosurfactant.

The crude biosurfactant was analyzed by reverse-phase HPLC (Fig. 4b) and LC-MS (Fig. 4c and d). The results showed that the biosurfactant extract contained at least 2 components. And the main peak showed ions at $m / z$ of $1036.50\left([\mathrm{M}+\mathrm{H}]^{+}\right), 1058.41([\mathrm{M}$ $\left.+\mathrm{Na}^{+}\right)$. The MS2 analysis of the mother ion 1036.50 showed a specific ion at $m / z 685.08$, which is a specific ion for surfactin type biosurfactant produced by Bacillus sp..$^{37,45}$ We further compared the fragmentation ions from the MS2 spectrum generated from the mother ion 1036.50 with those reported MS2 data of surfactins. ${ }^{3745}$ Taken all these together, the main biosurfactant produced by FA-2 was deduced to be $\mathrm{C}_{15}$ surfactin (Ile7 or Leu7). ${ }^{37}$
3.6 Measurement of CMC, emulsification capacity, biosurfactant stability

The crude surfactant reduced the surface tension of water from 64.7 to $31.2 \mathrm{mN} \mathrm{m}^{-1}$ as the biosurfactant concentration increased to $60 \mathrm{mg} \mathrm{l}^{-1}$ (Fig. 6). The surface tension did

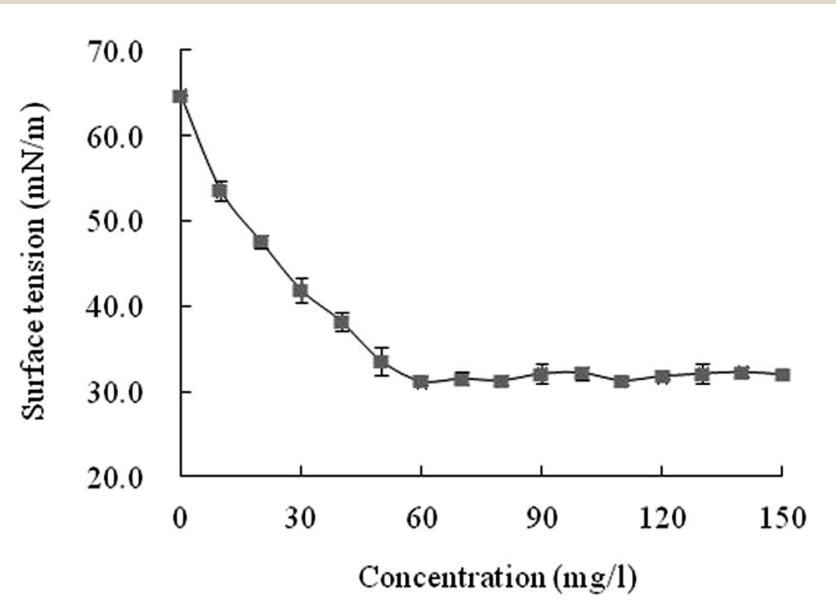

Fig. 6 Relationship between surface tension and the crude biosurfactant concentration anaerobically produced by FA-2.
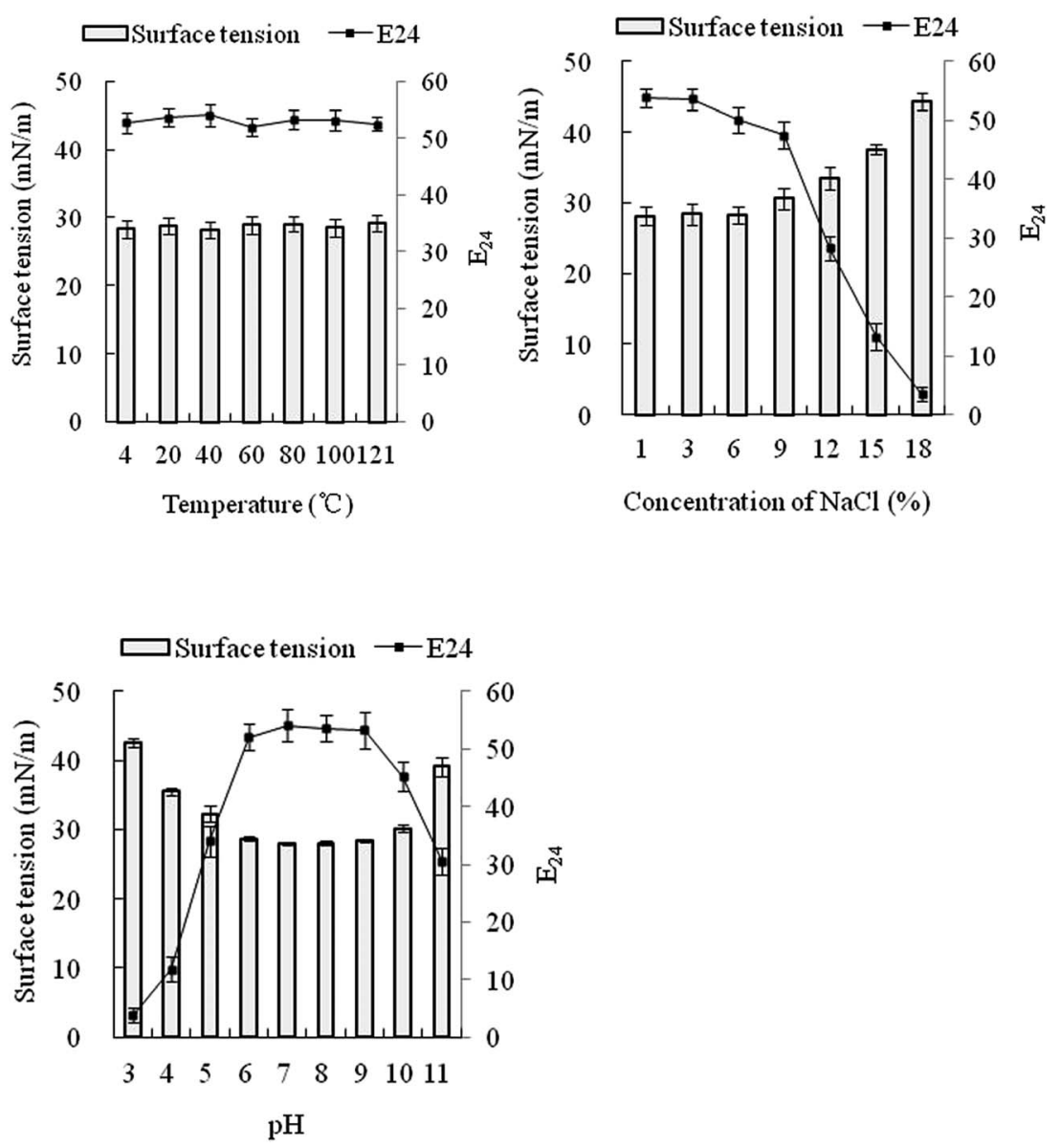

Fig. 5 Effect of temperature, $\mathrm{pH}$, and salinity on the stability of the biosurfactant produced by FA-2. Data points are the mean value of triplicate samples. 
Table 2 Emulsification index $\left(E_{24}\right)$ of the biosurfactant solution tested against various hydrocarbons. Data are means \pm standard deviation of 4 replicates

\begin{tabular}{lc}
\hline Hydrocarbon & $E_{24}(\%)$ \\
\hline Liquid paraffin & $53.2 \pm 1.3$ \\
$n$-Hexadecane & $50.0 \pm 0.9$ \\
Kerosene & $43.6 \pm 0.6$ \\
Olive oil & $53.3 \pm 1.1$ \\
$n$-Heptane & $45.7 \pm 1.3$ \\
Crude oil & $58.6 \pm 1.8$ \\
Xylene & $49.1 \pm 0.5$
\end{tabular}

not decrease further with increasing biosurfactant concentration and therefore the CMC was estimated at $60 \mathrm{mg} \mathrm{l}^{-1}$; close to that of the biosurfactant obtained by Nitschke and Pastore. $^{46}$

The results indicated the biosurfactant produced by FA- 2 was capable of emulsifying linear, cyclic, long-chain and short chain hydrocarbons as indicated by the maximum emulsification index values obtained with crude oil (Table 2).

Incubation of cell-free broth at various temperatures did not show any remarkable effect on the surface activity of the biosurfactant solution, therefore the biosurfactant substrate was deemed thermally stable (Fig. 5). However, activity of the biosurfactant solution was affected by $\mathrm{pH}$ and salinity. When $\mathrm{pH}$ was too acid, the surface tension was high and the $E_{24}$ values were low, comparable to surfactant-free controls with a surface tension of $66.9 \mathrm{mN} \mathrm{m}^{-1}$ and $E_{24}$ of 0 . The increase of salinity also decreased the surface activity of the biosurfactant.

\subsection{Growth of FA-2 in anaerobic fermentor}

During growth, $\mathrm{OD}_{600}$ increased slightly for the initial 21 hours and surface tension (ST) decreased from 62.9 to $55.6 \mathrm{mN} \mathrm{m}^{-1}$. After 21 hours, the $\mathrm{OD}_{600}$ began increasing exponentially and eventually entered a stationary phase at $51 \mathrm{~h}$ (Fig. 7). Meanwhile ST dropped dramatically and reached a minimum of $30.2 \mathrm{mN}$ $\mathrm{m}^{-1}$ at $54 \mathrm{~h}$. Afterwards, OD600 began to decrease and ST increased, because the death rate surpassed the reproduction rate. Biosurfactant yield was calculated by oil-spreading technique. The highest biosurfactant production rate occurred between 24 and $51 \mathrm{~h}$ with a largest diameter of $15 \mathrm{~mm}$. The results of cell growth, surface tension, and biosurfactant yield are consistent. During the fermentation, dissolved oxygen (DO) was maintained at $0 \mathrm{mg} \mathrm{l}^{-1}$ and oxidation-reduction potential remained below $0 \mathrm{mV}$ during the experiment, demonstrating that the fermentation was performed under strictly anaerobic conditions (Fig. 7).

\subsection{Recovery of crude oil from the physical simulating core}

Water flooding resulted in an oil recovery of $1.07 \%$ and water cut of $98 \%$ (Table 3). A bacterial suspension of FA-2 supplemented with nutrients equivalent to one PV was injected after water flooding to assess the potential enhancement of oil
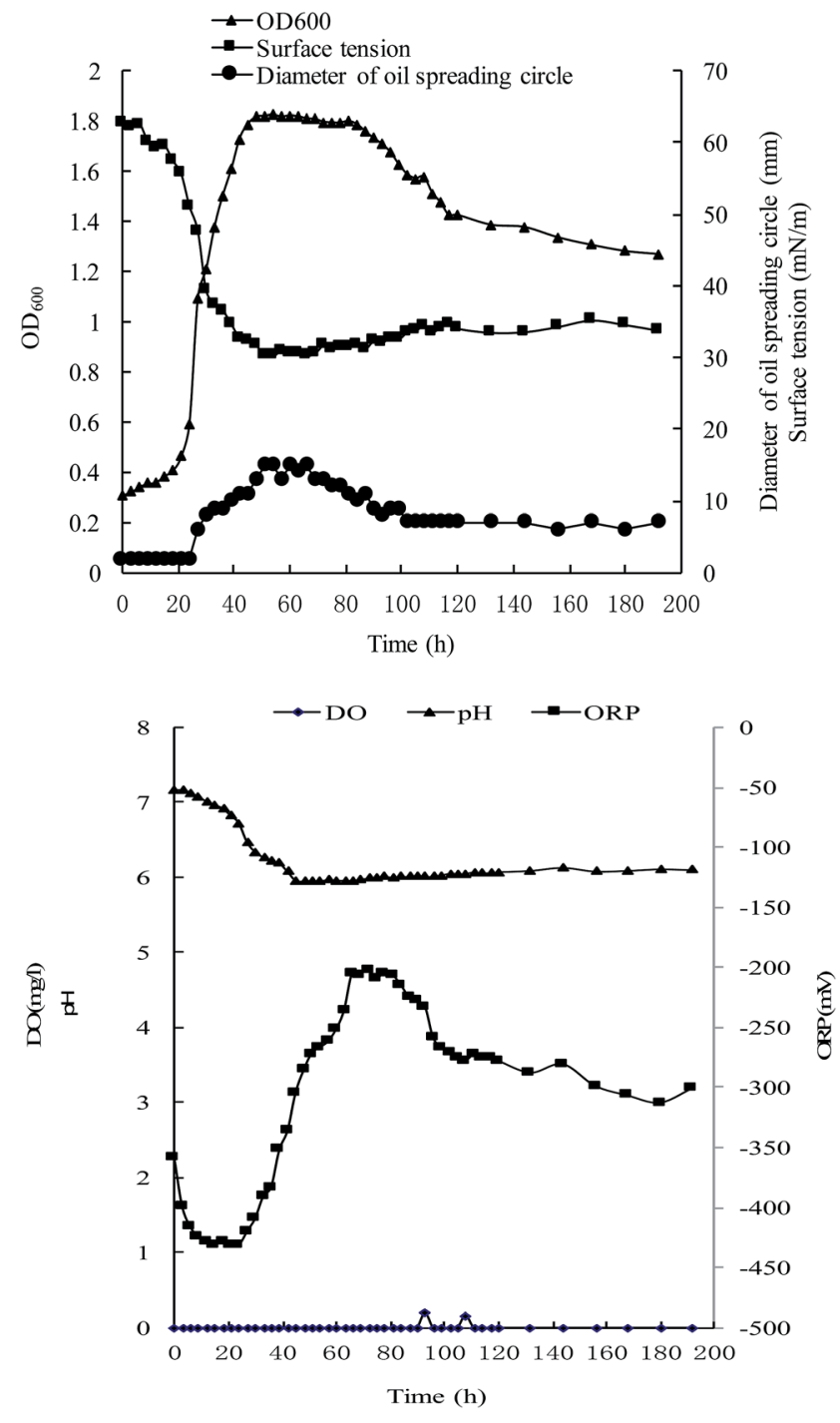

Fig. 7 Growth of FA-2 and surface tension of the culture broth under anaerobic fermentation at $37^{\circ} \mathrm{C}$, and changes in $\mathrm{pH}, \mathrm{DO}$ and ORP during the cultivation.

recovery by the surfactant-producing bacteria. The injected engineered bacteria produced lipopeptide by consuming supplemented nutrients in the core which was demonstrated by the surface tension reduction in the flood water. The MEOR value of the core was $5.22 \%$.

Most studies have been launched for lipopeptides production under aerobic moderate conditions, while more importance has been placed on biosurfactant production under extreme conditions. ${ }^{47}$ The yield of the lipopeptide C9-BS produced by $B$. subtilis $\mathrm{C} 9$ under $\mathrm{O} 2$-limited conditions was 3-fold higher than that under O2-sufficient conditions. ${ }^{48} \mathrm{C}$-BS exhibited high surface tension reducing capacity, smaller CMC value, and high level of thermal stability. A thermophilic Bacillus strain was isolated from a hydrocarbon containing medium for lipopeptide production at up to $50{ }^{\circ} \mathrm{C}$. Culture broth with produced lipopeptide had low surface and interfacial tension and recovered more than $95 \%$ of the residual oil 
Table 3 Results of physical simulation flooding test. The columns were first flooded with injected water until the water cut of produced liquid was higher than $98 \%$ to get the enhanced oil recovery (EOR). JZ-14 2 was then flooded by bacterial culture and JZ-14 20 was flooded by water

\begin{tabular}{|c|c|c|c|c|c|}
\hline 1 & JZ-14 2 & 56.82 & FA-2 (1.0) & 62.04 & 5.22 \\
\hline
\end{tabular}

from sandpack columns. ${ }^{9}$ The lipopeptide showed application potential in oil industries.

The anaerobically produced lipopeptide by FA-2 in this research had substantial surface reducing and emulsification capability for MEOR application. Youssef et al. studied the biosurfactant production by Bacillus in limestone petroleum reservoir and detected average $90 \mathrm{mg} \mathrm{l}^{-1}$ in produced fluids of inoculated wells which is about nine times the minimum concentration required to mobilize entrapped oil from sandstone cores. ${ }^{28}$ Further studies of Youssef et al.$^{49}$ in two oil wells found that the increase in oil recovery corresponded directly with biosurfactant production and $52.5 \mathrm{~m}^{3}$ of additional oil occurred in the first 60 days of sampling. The results in our work and previous studies showed the feasibility of stimulating in situ biosurfactant production and increase oil recovery from oil reservoirs.

\section{Conclusion}

We describe here the first engineered bacterial strain for anaerobic biosurfactant production under extreme environmental conditions by polyethylene glycol-induced protoplast fusion. The engineered strain (FA-2) showed mixed physiological phenotypes of both parents, B. mojavensis JF-2 and $P$. stutzeri DQ1, such as positive Gram reaction, rod shape, anaerobic biosurfactant production, rapid anaerobic growth, and adaptability to extreme environments. FA-2 produced similar lipopeptide anaerobically with that of B. mojavensis JF2. The capacity of lipopeptide production remained stable even subcultured continually which demonstrated stable genetic characteristics and reliable potential in field trial. The flexibility and adaptability of FA-2 under extreme conditions was emphasized, since this bacterial strain was aimed at in situ application for MEOR. FA-2 functioned well at temperatures up to $50^{\circ} \mathrm{C}, \mathrm{pH}$ range of $4.5-10.0$, and salt concentrations as high as $10 \%$. The fermentor tests confirmed the mass growth and biosurfactant production of FA-2 under anaerobic conditions. The MEOR value of the core flooding experiment simulating oil reservoir conditions was $5.22 \%$. Therefore, bioaugmentation of FA-2 will be a promising approach for in situ MEOR.

\section{Acknowledgements}

The authors are grateful to Prof. Hanping Dong for his assistance in core flooding experiments. This research was financially supported by the National High Technology Research and Development Program of China (No. 2013AA064402) and the National Natural Science Foundation of China (31570121).

\section{References}

1 I. M. Banat, A. Franzetti, I. Gandolfi, G. Bestetti, M. G. Martinotti, L. Fracchia, T. J. Smyth and R. Marchant, Appl. Microbiol. Biotechnol., 2010, 87, 427-444.

2 R. Sen, Prog. Energy Combust. Sci., 2008, 34, 714-724.

3 I. M. Banat, R. S. Makkar and S. S. Cameotra, Appl. Microbiol. Biotechnol., 2000, 53, 495-508.

4 D. A. Vaz, E. J. Gudiña, E. J. Alameda, J. A. Teixeira and L. R. Rodrigues, Colloids Surf., B, 2012, 89, 167-174.

5 Y. Al-Wahaibi, S. Joshi, S. Al-Bahry, A. Elshafie, A. Al-Bemani and B. Shibulal, Colloids Surf., B, 2014, 114, 324-333.

6 A. K. Yadav, S. Manna, K. Pandiyan, A. Singh, M. Kumar, H. Chakdar, P. L. Kashyap and A. K. Srivastava, Microbiology, 2016, 85, 56-62.

7 A. Lawrance, M. Balakrishnan, T. C. Joseph, D. P. Sukumaran, V. N. Valsalan, D. Gopal and K. Ramalingam, Mar. Pollut. Bull., 2016, 82, 76-85.

8 X. Li, A. Li, C. Liu, J. Yang, F. Ma, N. Hou, Y. Xu and N. Ren, Process Biochem., 2012, 47, 626-634.

9 I. M. Banat, Biotechnol. Lett., 1993, 15, 591-594.

10 P. Gao, H. Tian, Y. Wang, Y. Li, Y. Li, J. Xie, B. Zeng, J. Zhou, G. Li and T. Ma, Sci. Rep., 2016, 6, 20174.

11 A. Vigneron, E. B. Alsop, B. Chambers, B. P. Lomans, I. M. Head and N. Tsesmetzis, Appl. Environ. Microbiol., 2016, 82, 2545-2554.

12 W. Zhu, J. Zhao, H. Han, G. Sun and Z. Song, Energy Fuels, 2015, 29, 7866-7874.

13 J. Patel, S. Borgohain, M. Kumar, V. Rangarajan, P. Somasundaran and R. Sen, Renewable Sustainable Energy Rev., 2015, 52, 1539-1558.

14 H. Ghojavand, F. Vahabzadeh, M. Mehranian, M. Radmehr, K. A. Shahraki, F. Zolfagharian, M. A. Emadi and E. Roayaei, Appl. Microbiol. Biotechnol., 2008, 80, 1073-1085.

15 E. J. Gudiña, J. F. Pereira, L. R. Rodrigues, J. A. Coutinho and J. A. Teixeira, Int. Biodeterior. Biodegrad., 2012, 68, 56-64.

16 J. F. Pereira, E. J. Gudiña, R. Costa, R. Vitorino, J. A. Teixeira, J. A. Coutinho and L. R. Rodrigues, Fuel, 2013, 111, 259-268.

17 D. R. Simpson, N. R. Natraj, M. J. McInerney and K. E. Duncan, Appl. Microbiol. Biotechnol., 2011, 91, 10831093.

18 S. M. Dastgheib, M. A. Amoozegar, E. Elahi, S. Asad and I. M. Banat, Biotechnol. Lett., 2008, 30, 263-270. 
19 P. Gao, G. Li, Y. Li, Y. Li, H. Tian, Y. Wang, J. Zhou and T. Ma, Front. Microbiol., 2016, 7, 186.

20 D. H. Noh, J. B. Ajo-Franklin, T. H. Kwon and B. Muhunthan, J. Geophys. Res.: Biogeosci., 2016, 121, 1158-1177.

21 S. De, S. Malik, A. Ghosh, R. Saha and B. Saha, RSC Adv., 2015, 5, 65757-65767.

22 L. J. Chai, F. Zhang, Y. H. She, I. M. Banat and D. J. Hou, Nat., Environ. Pollut. Technol., 2015, 14, 455.

23 S. Sun, Y. Luo, S. Cao, W. Li, Z. Zhang, L. Jiang, H. Dong, L. Yu and W. Wu, Bioresour. Technol., 2013, 144, 44-49.

24 Y. Xu and M. Lu, J. Pet. Sci. Eng., 2011, 78, 233-238.

25 M. Folmsbee, K. Duncan, S. O. Han, D. Nagle, E. Jennings and M. McInerney, Syst. Appl. Microbiol., 2006, 29, 645-649.

26 G. E. Jenneman, M. J. McInerney, R. M. Knapp, J. B. Clark, J. M. Feero, D. E. Revus and D. E. Menzie, Dev. Ind. Microbiol., 1983, 24, 485-492.

27 R. T. Armstrong and D. Wildenschild, Int. J. Petrol. Sci. Tech., 2012, 94, 155-164.

28 N. Youssef, D. R. Simpson, K. E. Duncan, M. J. McInerney, M. Folmsbee, T. Fincher and R. M. Knapp, Appl. Environ. Microbiol., 2007, 73, 1239-1247.

29 M. J. Folmsbee, M. J. McInerney and D. P. Nagle, Appl. Environ. Microbiol., 2004, 70, 5252-5257.

30 S. C. Lin, K. S. Carswell, M. M. Sharma and G. Georgiou, Appl. Microbiol. Biotechnol., 1994, 41, 281-285.

31 M. Javaheri, G. E. Jenneman, M. J. McInerney and R. M. Knapp, Appl. Environ. Microbiol., 1985, 50, 698-700.

32 X. Liang, F. Zhao, R. Shi, Y. Ban, J. Zhou, S. Han and Y. Zhang, Yingyong Shengtai Xuebao, 2015, 26, 2553-2560.

33 N. H. Youssef, K. E. Duncan, D. P. Nagle, K. N. Savage, R. M. Knapp and M. J. McInerney, J. Microbiol. Methods, 2004, 56, 339-347.

34 M. E. Mercade, M. A. Manresa, M. Robert, M. J. Espuny, C. De Andres and J. Guinea, Bioresour. Technol., 1993, 43, 1-6.
35 J. B. Clark, D. M. Munnecke and G. E. Jenneman, Dev. Ind. Microbiol., 1981, 22, 695-701.

36 D. G. Cooper, C. R. Macdonald, S. J. Duff and N. Kosaric, Appl. Microbiol. Biotechnol., 1981, 42, 408-412.

37 Z. Ma and J. Hu, Appl. Biochem. Biotechnol., 2015, 177, 15201529.

38 A. Ghosh, R. Saha and B. Saha, J. Ind. Eng. Chem., 2014, 20, 345-355.

39 D. G. Cooper and B. G. Goldenberg, Appl. Microbiol. Biotechnol., 1987, 53, 224-229.

40 L. R. Rodrigues, J. A. Teixeira, H. C. van der Mei and R. Oliveira, Colloids Surf., B, 2006, 49, 79-86.

41 M. Morikawa, Y. Hirata and T. Imanaka, Biochim. Biophys. Acta, Mol. Cell Biol. Lipids, 2000, 1488, 211-218.

42 C. Dejwatthanakomol, J. Anuntagool, M. Morikawa and J. Thaniyavarn, Sci. Asia, 2016, 42, 252-258.

43 A. F. de Faria, D. S. Teodoro-Martinez, G. N. de Oliveira Barbosa, B. G. Vaz, Í. S. Silva, J. S. Garcia, M. R. Tótola, M. N. Eberlin, M. Grossman, O. L. Alves and L. R. Durrant, Process Biochem., 2011, 46, 1951-1957.

44 X. Huang, J. N. Liu, Y. Wang, J. Liu and L. Lu, Biotechnol. Biotechnol. Equip., 2015, 29, 381-389.

45 J. S. Tang, F. Zhao, H. Gao, Y. Dai, Z. H. Yao, K. Hong, J. Li, W. C. Ye and X. S. Yao, Mar. Drugs, 2010, 8, 2605-2618.

46 M. Nitschke and G. M. Pastore, Bioresour. Technol., 2006, 97(2), 336-341.

47 S. S. Cameotra and R. S. Makkar, Appl. Microbiol. Biotechnol., 1998, 50, 520-529.

48 H. S. Kim, B. D. Yoon, C. H. Lee, H. H. Suh, H. M. Oh, T. Katsuragi and Y. Tani, J. Ferment. Bioeng., 1997, 84, 4146.

49 N. Youssef, D. R. Simpson, M. J. McInerney and K. E. Duncan, Int. Biodeterior. Biodegrad., 2013, 81, 127132. 